\title{
Mapping Three-Dimensional Density Patterns for Analyzing Artefact (Re)distribution Trends in Palaeolithic Sites
}

\author{
Rosalia Gallotti ${ }^{1}$, Giuseppe Lembo ${ }^{2}$, Carlo Peretto ${ }^{2}$ \\ ${ }^{1}$ Université Bordeaux, UMR 5199 PACEA PPP, Talence, France \\ ${ }^{2}$ Sezione Paleobiologia, Preistoria ed Antropologia, Dipartimento di Biologia ed Evoluzione, \\ Università degli Studi di Ferrara, Ferrara, Italy \\ Email: rosalia.gallotti@u-bordeaux1.fr
}

Received February $5^{\text {th }}, 2012$; revised March $20^{\text {th }}, 2012$; accepted March $30^{\text {th }}, 2012$

\begin{abstract}
The artefact density in an archaeological deposit provides a direct record of the concentrating and dispersing effects of various formation processes. 2D density analyses have frequently been processed, especially through the topological properties of the Geographical Information System. Nevertheless, the resulting 2D visualisation by density maps does not consider or analyze the vertical interpolation of archaeological finds. This is limiting in the case of very thick archaeostratigraphic units, where the 3D visualisation of the density phenomena provides a basic tool for a better understanding of the real spatial distribution trends of archaeological remains. In this paper, we propose a new method for processing 3D density analyses, and we present its first application to the Middle Pleistocene site of Isernia La Pineta as a further step towards distinguishing the impact of natural and anthropogenic processes on site formation and stratogenesis.
\end{abstract}

Keywords: Intra-Site Spatial Analyses; 3D Density Patterns; Site Formation Processes; Geographical Information System; Middle Pleistocene; Isernia La Pineta

\section{Introduction}

The spatial distribution of archaeological remains in Palaeolithic sites rarely reflects an undisturbed state of abandon by humans. Frequently, complex post-depositional phenomena, which can be anthropogenic or natural, alter the initial humaninduced site patterning and produce multi-genesis palimpsests (Bailey, 2007; D'Andrea \& Gallotti, 2004; D'Andrea et al., 2002; Malinsky-Buller et al., 2011; Schiffer, 1983; Texier, 2000).

Especially in the case of very rich archaeostratigraphic units resulting from long-lasting human occupation and/or corresponding to palimpsests, the increase and/or overlapping of activity areas along with natural disturbance mechanisms strongly limit our ability to recognize clear-cut distribution trends and interpret their socio-economic and behavioural meaning (Yellen, 1977; Djindjian, 1999).

By considering the numerous potential disturbance factors, intra-site spatial analyses, integrated in a multidisciplinary approach for determining the mechanisms that have contributed to sedimentation, nowadays appear to be among most advanced techniques of spatial investigation for estimating the role of burial processes. The identification of these processes should precede behavioural inference that uses evidence from the archaeological record (Blankholm, 1991; D'Andrea \& Gallotti, 2004; D'Andrea et al., 2002; Djindjian, 1988, 1999; Hodder \& Orton, 1976; Johnson, 1976; Kintigh \& Ammermann, 1982; Simek, 1984; Whallon, 1984; Wheatley \& Gillings, 2002).

In the last two decades these techniques have been frequently processed through the topological properties of the Geographical Information System (GIS). This has been employed for a long time in archaeological landscape studies (Petrie et al.,
1995) and has recently been applied to interpretations of intrasite spatial distribution trends of artefacts (Benito-Calvo \& de la Torre, 2011; Cooper \& Qiu, 2006; Craig et al., 2006; D'Andrea et al., 2000, 2002; Gallotti \& Piperno, 2004; Gallotti et al., 2004, 2011; Lembo \& Gallotti, 2006; Nigro et al., 2001, 2003; Peretto et al., 2010; Thomas et al., 1996; Vullo et al., 1999).

Among the most useful spatial techniques is density analysis of artefacts (Jerardino, 1995; Johnson, 1976; Schagen, 1986), which is able to recognize concentration and dispersing trends in artefacts (re)distribution (Schiffer, 1983). The density function calculates the quantity of points in a level on a continuous surface. Thus, the occurrence and, in particular, the closeness of points is highlighted through the generation of a new two-dimensional map of density values beginning from a given point Values are expressed through density curves quantified on the basis of a k-nearest neighbour distance calculated from the centroid of the objects. Proximity function in the GIS performs this analysis by creating a buffer zone around each artefact point (Mitchell, 1999).

However, the resulting two-dimensional map does not consider and analyze the vertical dispersal of finds. Unfortunately, the two-dimensional model is not always appropriate for conducting spatial analyses in thick archaeostratigraphic units, where the vertical interpolation influences the two-dimensional representation of spatial patterns. Until recently this has received relatively little attention in the specialist literature, likely due to certain limitations of conventional GIS software (Moyes, 2002; Spikins et al., 2002).

Previously, the tree-dimensional representation of density analyses has been approached in only two instances (Barceló, 2002; Baxter et al, 1997; Beardah, 1999; Beardah \& Baxter, 


\section{R. GALLOTTI ET AL.}

1999; Nigro et al., 2003). In an attempt to bypass this obstacle, we have created a user-friendly software (DA3D) that calculates a three-dimensional density function. Resulting calculations were performed by Voxler $^{\mathcal{O}}$, a three-dimensional visualisation software. Finally, we present the first results from the application of this new technique, as carried out at the Early Middle Pleistocene site of Isernia La Pineta (Molise, Italy).

\section{Isernia La Pineta Archaeological Context}

The site of Isernia La Pineta is located at an elevation of ca. $400 \mathrm{~m}$ a.s.l. in the Upper Volturno Basin at the periphery of the town of Isernia in Central Italy (Figure 1(a)). It represents the oldest and morphostratigraphically highest Pleistocene sedimentological unit described in the basin (Coltorti, 1983; Van Otterloo \& Sevink, 1983).

Isernia La Pineta is one of the earliest Italian archaeological sites (Coltorti et al., 2005; Shao et al., 2011) and is one of the key sites for our understanding of human behavior at the begin- ning of the Middle Pleistocene. Numerous faunal remains and a core and flake industry have been found within a thick stratigraphy composed of fluvial, lacustrine and volcanic sediments (Anconetani et al., 1992; Coltorti et al., 1982; Cremaschi, 1983; Cremaschi \& Peretto, 1988; Peretto et al., 2004). The deposit has been excavated in two different sectors: Sector I of about $250 \mathrm{~m}^{2}$ (the present area of excavation is covered by a pavilion), and Sector II of $90 \mathrm{~m}^{2}$, investigated at the beginning of $1980 \mathrm{~s}$ (Peretto, 1999).

The stratigraphy of the site (Figures 1(b), (c)) has been described mainly by Coltorti \& Cremaschi (1982) and by Cremaschi (1983), who recognized the following units (listed from the base of the section, upwards): Unit 5, lacustrine clays with thin layers of gravels and debris; Unit 4, travertines; Unit 3, palustrine deposits with sands and fine gravels; Unit 2, sands and gravels; Unit 1, gravels and sands with intercalated tuffs. Unit 3 contains the archaeological deposits and it is composed of the following sub-units in Sector I (again listed from the base

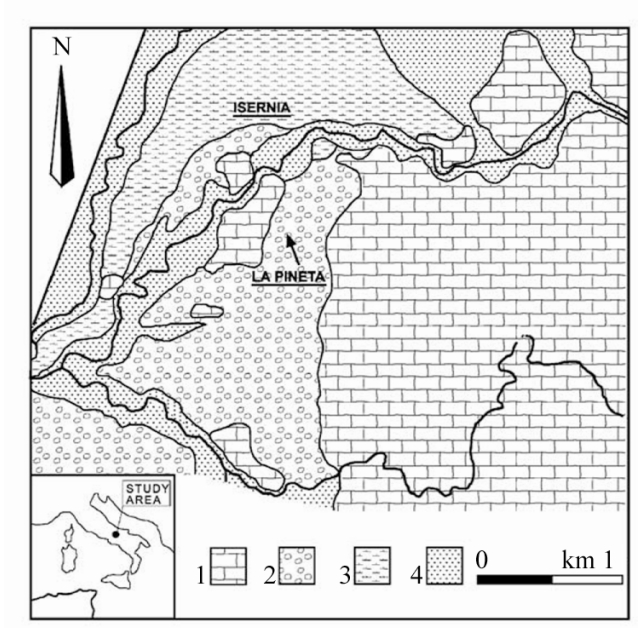

(a)

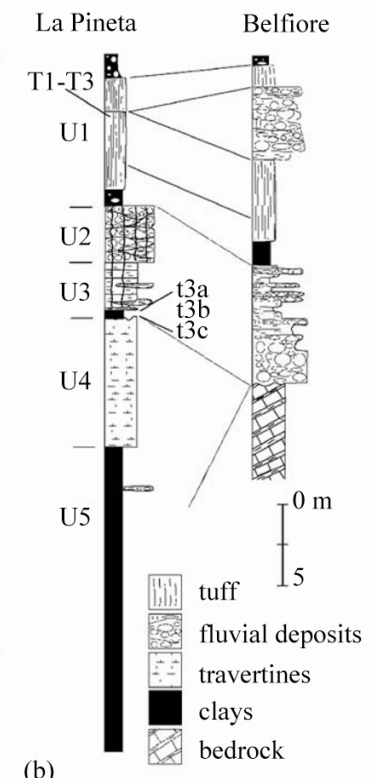

(b)

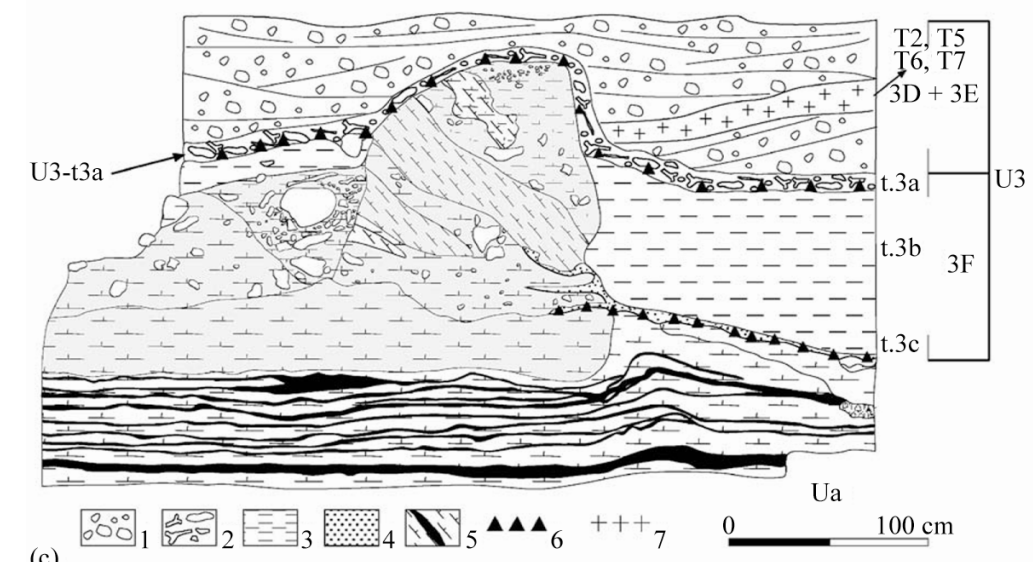

Figure 1.

Stratigraphic setting and location of the site. (a) 1, limestone bedrock; 2, main filling of the basin; 3, travertines; 4, recent fluvial deposits; (b) Stratigraphic sequence of Isernia La Pineta and Villa Belfiore with the indication of the lithological units utilised by Cremaschi (1993); 1C, detailed stratigraphy of Unit 3 in Sector I (after Coltorti et al., 2005). 
of the unit):

3F: this sub-unit is subdivided into three layers:

t. $3 \mathrm{c}$ - archaeological and paleontological remains lying on phytoclastic travertine of the Unit 4;

t.3b-alluvial muddy-clayey covering t.3c, archaeologically sterile;

t.3a - the main occupation level lying on top of the clay layer and travertines, composed of a high concentration of flint and limestone artefacts, faunal remains that mostly consist of large bones, and reworked natural elements of travertine;

$3 \mathrm{E}$ (or 3coll): pyroclastic layer (debris-flow) composed of up to $30-100 \mathrm{~cm}$ thick unit of reworked and well sorted elements including large crystals of sanidine (with a ${ }^{40} \mathrm{Ar} /{ }^{39} \mathrm{Ar}$ age of 610 \pm 10 and $606 \pm 2 \mathrm{ka}$; Coltorti et al., 2005), and pyroxene. This sub-unit is usually rich in archaeological materials;

3D: gravels, coarse sands and finer sediments of ca. $150 \mathrm{~cm}$ thick, divided in two artificial splits: $3 s 1-5$ and 3s6-9. Lithic and faunal remains are scattered throughout the entire thickness of this subunit. The number of finds recorded to present is summarized in Table 1.

The faunal remains are predominantly bison, elephant and rhinoceros. Less common are megaceros, red deer, fallow deer, thar and hippopotamus. Amongst the carnivores, bear is frequent, and lion is known from a single ferine tooth (Peretto, 1996; Peretto et al., 2004). Impact areas caused by intentional fracturing are evident on a great number of bones from the entire stratigraphic sequence; striations related to butchery with lithic tools are sometimes visible (Thun Hohenstein et al., 2002).

The main goals of lithic production are the flaking activities, on both flint and limestone. The flint has often been worked using the bipolar technique on anvil (Peretto et al., 2004).

\section{Background on Previous Spatial Analyses at Isernia La Pineta}

The t.3a excavation in Sector I has yielded the greatest quantity of paleontological remains. It is located directly above the travertine of the Unit 4 in the SW part; northward, it lies on mudstone (t.3b). This discontinuity gradually becomes less marked towards the NE, and the materials are contained within muddy-clayey layers (Cremaschi, 1983). Cross-bedded fine gravelly sands $3 \mathrm{E}$ (3coll) containing reworked archaeological elements cover the deposits and are interlayered with tuffs very rich in pyroxene and sanidine.

In previous studies, t.3a of Sector I has been interpreted as a single depositional and anthropogenic event ("living floor"), it has been labeled as an "archaeosurface" and behavioral interpretation has been deduced from the analysis of the spatial distribution of finds (Peretto, 1999; Peretto et al., 2004). This is

Table 1.

Isernia La Pineta. Number of finds recorded per stratigraphic unit.

\begin{tabular}{|c|c|c|c|c|c|}
\hline & $\begin{array}{c}t .3 \mathrm{c} \\
\left(52 \mathrm{~m}^{2}\right)\end{array}$ & $\begin{array}{c}t .3 a \\
\left(167 \mathrm{~m}^{2}\right)\end{array}$ & $\begin{array}{c}3 E \\
\left(82 \mathrm{~m}^{2}\right)\end{array}$ & $\begin{array}{c}3 s 6-9 \\
\left(81 \mathrm{~m}^{2}\right)\end{array}$ & $\begin{array}{c}3 s 1-5 \\
\left(65 \mathrm{~m}^{2}\right)\end{array}$ \\
\hline Lithic artefacts & 451 & 4056 & 6051 & 2554 & 653 \\
\hline Faunal remains & 388 & 7432 & 5235 & 2791 & 1045 \\
\hline Natural materials & 230 & 7871 & 693 & 314 & 0 \\
\hline Total & 1069 & 19,359 & 11,979 & 5659 & 1698 \\
\hline
\end{tabular}

likely due to the existence of a general consensus (possibly unfounded) broadly shared in previous years over the primary position of this Lower Paleolithic deposit. Given the finegrained contexts in which assemblages are located and the mainly fresh condition of artefacts and bones, it is widely agreed that $\mathrm{t} .3 \mathrm{a}$ experienced no major postdepositional disturbance. Furthermore, the idea of a "living floor" has been effectively induced during the first years of excavation based on two main factors: 1) the presence of numerous large anatomical elements together with lithic industry lying on a sub-horizontal surface creating a sort of anthropic "pavage"; 2) the partial destruction of the upper part of the stratigraphic sequence by the beginning of works for construction of the Naples-Vasto highway. This event did not permit a detailed analysis of the stratigraphic relationship between t.3a and $3 \mathrm{E}$ in the western part of the excavated area.

In order to investigate the patterns of the spatial distribution of finds in the archaeostratigraphic units, a specific GIS for the mapping and analysis of fossil deposits at Isernia La Pineta has been developed. Due both to the extent of the investigated area and the number of finds, the adoption of a GIS was indispensable for data management and for performing spatial statistical techniques.

This GIS application, developed since 2001 (Gallotti, 2004; Gallotti et al., 2004), permitted the following operations:

- conversion of paper archives of previous excavations (19781999) into digital format;

- three-dimensional location of all finds from the new excavations (2000-present) collected using a total station;

- processing of archaeological entities as spatial variables;

- spatial interrogations for creating thematic maps (Figure 2(a)) and cross-sections (Figure 2(e)). A vector model, representing features as points or polygons for plans, and as points for cross-sections, was used. Cross-sections correspond effectively to a two-dimensional representation: by ranging the values of $x$ or $y$, respectively, on the abscissa, and those of $\mathrm{z}$ on the ordinate, it was possible to plot the projection of all finds for mapping transversal and longitudinal sections. Thus, this operation does not correspond to a true three-dimensional space management;

- statistical inference of two-dimensional spatial data (frequency matrixes, density analyses) to highlight distribution patterns (Figures 2(b), (c), (d)).

These GIS-based analyses highlight that spatial patterns at t.3a, considered globally, appear to be random. Although analyzed for single categories, the spatial distribution trends in the central and eastern part of this archaeosurface do not differ significantly from a uniform model. This datum is expected from archaeological and/or paleontological concentrations disturbed by natural agents and it is uncharacteristic of in situ assemblages.

Nevertheless, when analyzing the spatial trends of the various categories of finds, it appears to be possible that some zones in the SW part of Sector I directly above the travertine of the Unit 4 may harbor some associations due to anthropogenic action, as a flint knapping area, where products and by-products of the same chaînes opératoire aimed at different output are concentrated (Figure 2(b)).

\section{Method}

The method of the three-dimensional density analysis was 

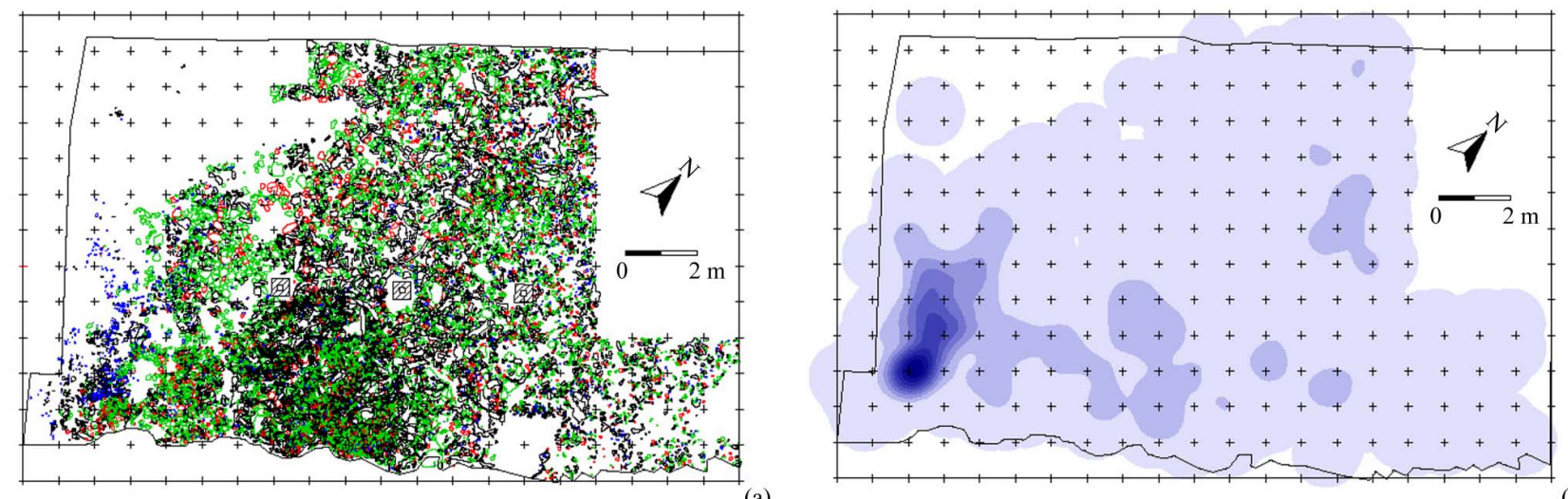

(a)

(b)
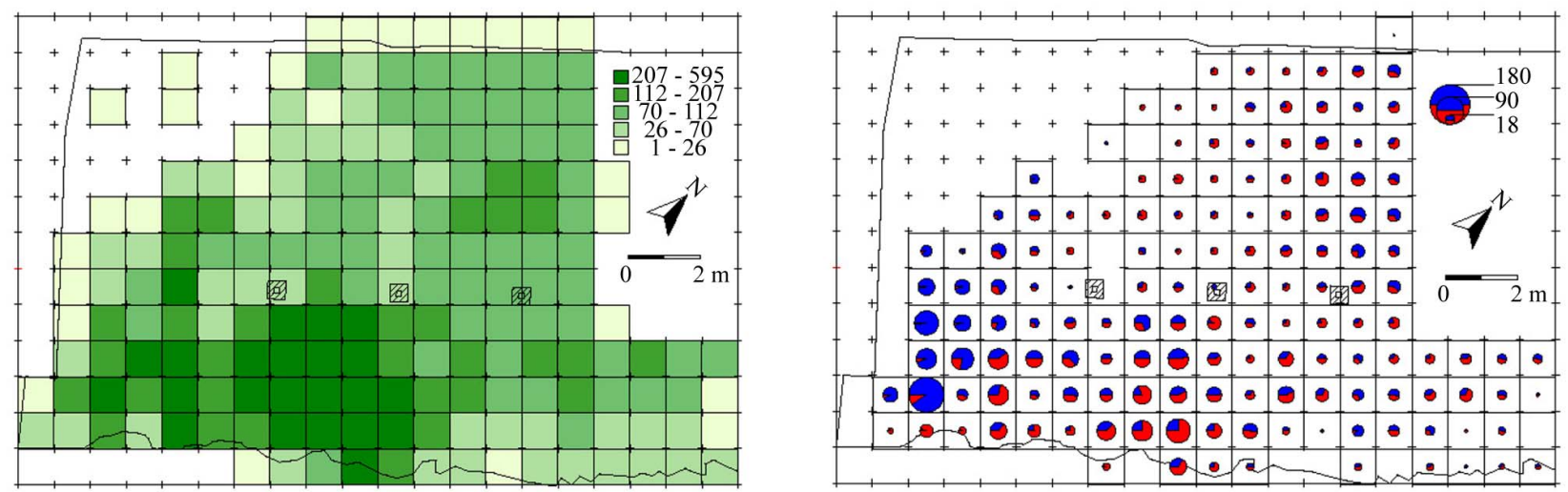

(c)

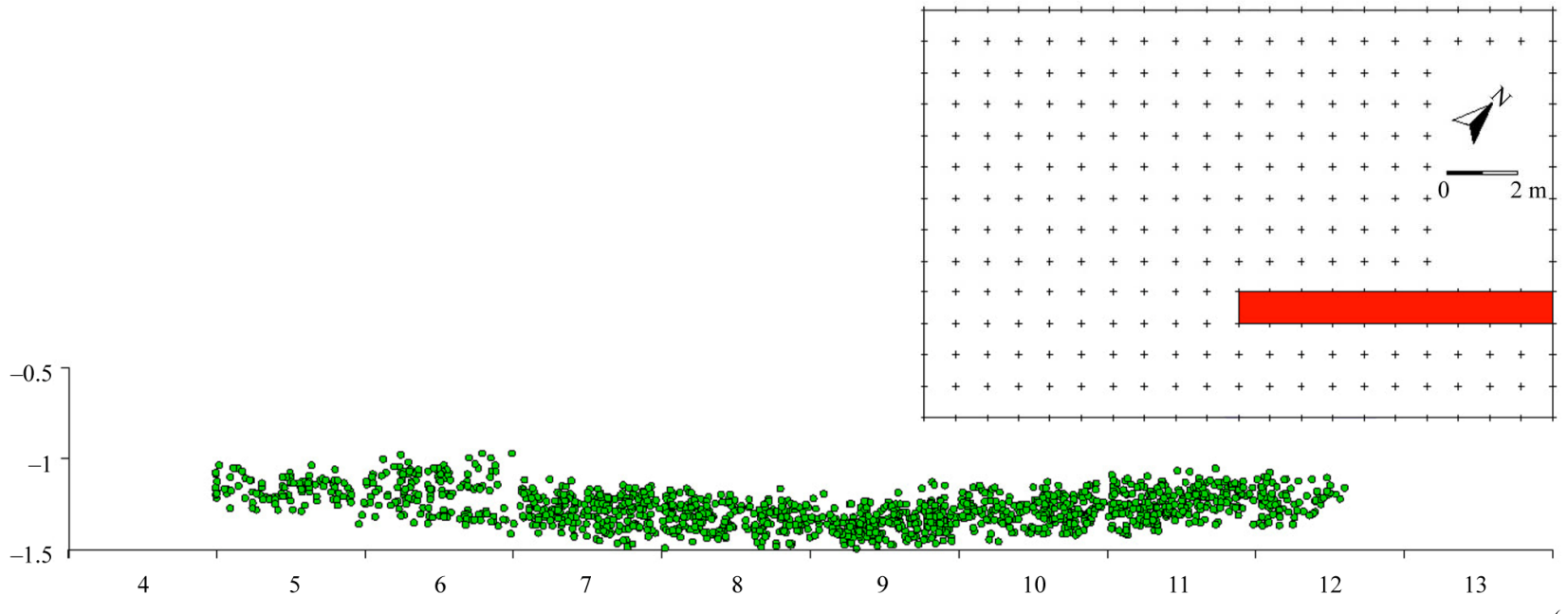

(e)

Figure 2.

Isernia La Pineta, Sector I. (a) t.3a — distribution of all remains (red: limestone; blue: flint; black: faunal elements; green: travertine); (b) t.3a — twodimensional density map of flint; (c) t.3a - frequencies per square meter of all remains; (d) t.3a—chart map with the relationship between flint (blue) and limestone (red); (e) 3E: longitudinal projection of all remains.

processed in 2009 following the development of the GIS. The complexity of the depositional phenomena and the thickness of the stratigraphic sequence required the mapping and spatial analysis of a true three-dimensional distribution of finds. For this goal we created a software package (DA3D) with the ability to count the number of finds (points) within a sphere at a variable radius, whose center is a given point corresponding to the centroid (geometric center) of each find. This counting results from the Euclidean distance calculation for measuring the space from the center of the sphere to the center of all other points in the dataset. If this distance is equal to or less than the radius of the sphere, the point is counted. 
Thus,

Set of archaeological objects: $\mathrm{A}\left(\mathrm{x}_{\mathrm{A}}, \mathrm{y}_{\mathrm{A}}, \mathrm{z}_{\mathrm{A}}\right), \mathrm{B}\left(\mathrm{x}_{\mathrm{B}}, \mathrm{y}_{\mathrm{B}}, \mathrm{z}_{\mathrm{B}}\right), \mathrm{C}\left(\mathrm{x}_{\mathrm{C}}\right.$, $\left.\mathrm{y}_{\mathrm{C}}, \mathrm{z}_{\mathrm{C}}\right) \cdots \mathrm{N}\left(\mathrm{x}_{\mathrm{N}}, \mathrm{y}_{\mathrm{N}}, \mathrm{z}_{\mathrm{N}}\right)$

for each ( $\mathrm{P}_{\mathrm{A}}$ in Points)

for each $\left(\mathrm{P}_{\mathrm{B}}\right.$ in Points)

if $\left(\mathrm{k} \leq \mathrm{d}\left(\mathrm{P}_{\mathrm{A}}, \mathrm{P}_{\mathrm{B}}\right)\right)$ where:$$
\text { count }\left(\mathrm{P}_{\mathrm{A}}\right)++
$$

$\mathrm{P}=$ dataset for density calculation. Example: $\mathrm{P}_{\mathrm{A}}$ is the set of points considered for counting and the centre of the sphere is the point $\mathrm{A}$

$\mathrm{k}=$ radius of the sphere

$\mathrm{d}($ Euclidean distance $)=$

$\sqrt{\left(\mathrm{x}_{\mathrm{P}_{\mathrm{A}}}-\mathrm{x}_{\mathrm{P}_{\mathrm{B}}}\right)^{2}+\left(\mathrm{y}_{\mathrm{P}_{\mathrm{A}}}-\mathrm{y}_{\mathrm{P}_{\mathrm{B}}}\right)^{2}+\left(\mathrm{z}_{\mathrm{P}_{\mathrm{A}}}-\mathrm{z}_{\mathrm{P}_{\mathrm{B}}}\right)^{2}}$

The complexity of the algorithm is $\mathrm{O}\left(\mathrm{n}^{2}\right)$.

A schematic example is given in Figure 3.

The database obtained from the data processing in DA3D was imported to Voxler ${ }^{\circ}$, a three-dimensional scientific visualization program, primarily oriented toward volumetric rendering and three-dimensional data display. While the emphasis is on three-dimensional volumes, Voxler ${ }^{\mathcal{O}}$ can also utilize two-

$$
\mathrm{P}_{\mathrm{A}}
$$
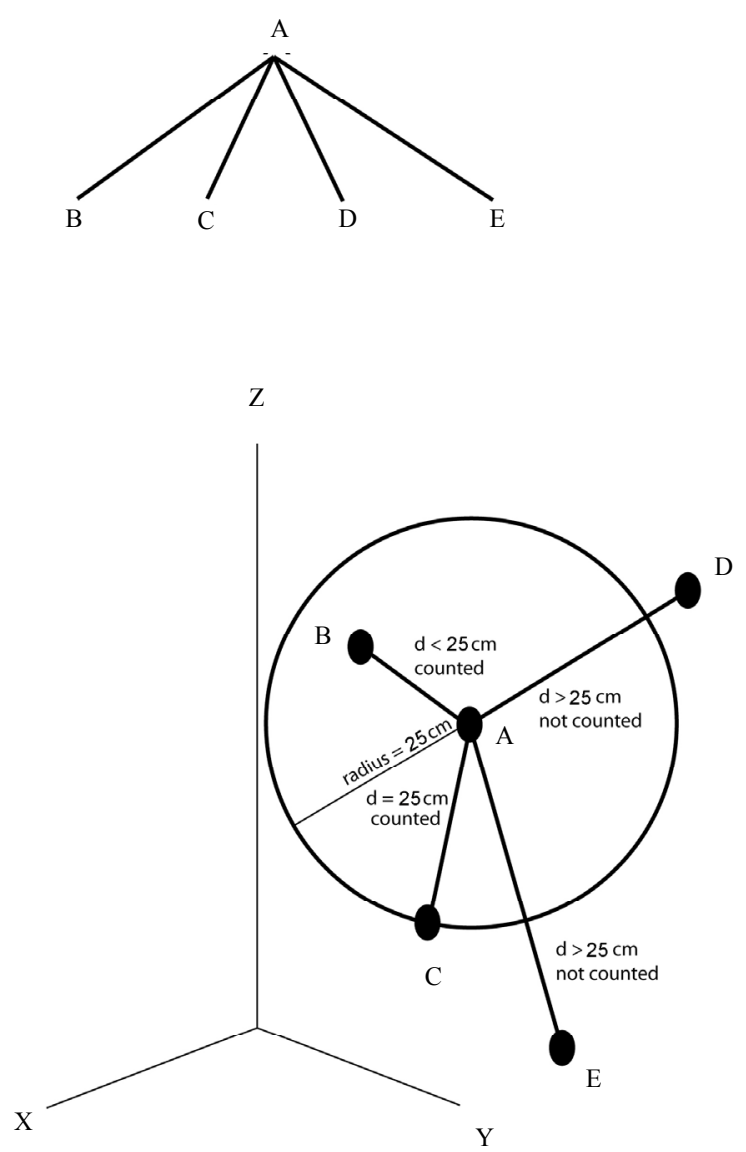

Figure 3.

Schematic representation of the density calculating method. dimensional grids including DEM files, images, and scattered point data. Voxler $^{\mathcal{O}}$ can display streamlines, vector plots, contour maps, isosurfaces, image slices, three-dimensional scatter plots, and direct volume rendering, among others. Computational modules include three-dimensional gridding (performed using inverse distance and local polynomial gridding method), resampling, numerous lattice operations, and image processing.

Using the three-dimensional lattice properties, a sphere at a variable radius was visualized around each point. A three-dimensional thematic map for ranges of values can be created starting from the density values contained in the database associated to the point set (Figure 4).

It is also possible to explore the density patterns using the functions of clipPlane and orthoimage: one or more orthogonal or oblique planes can be visualized and moved across the threedimensional density map. Thus, the map can be cut in any position and in any angle. Additionally, several two- and/or threedimensional maps can be viewed simultaneously or separately.

\section{Preliminary Results}

As described above, random spatial distribution of finds has $\mathrm{P}_{\mathrm{B}}$
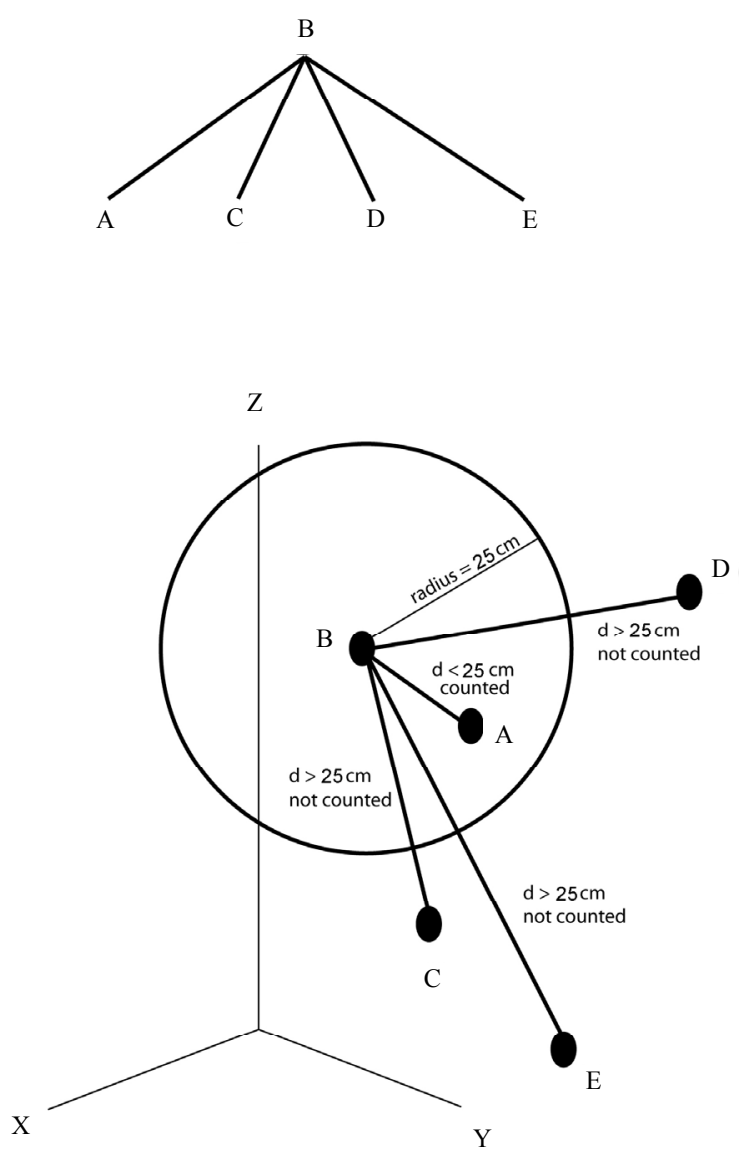


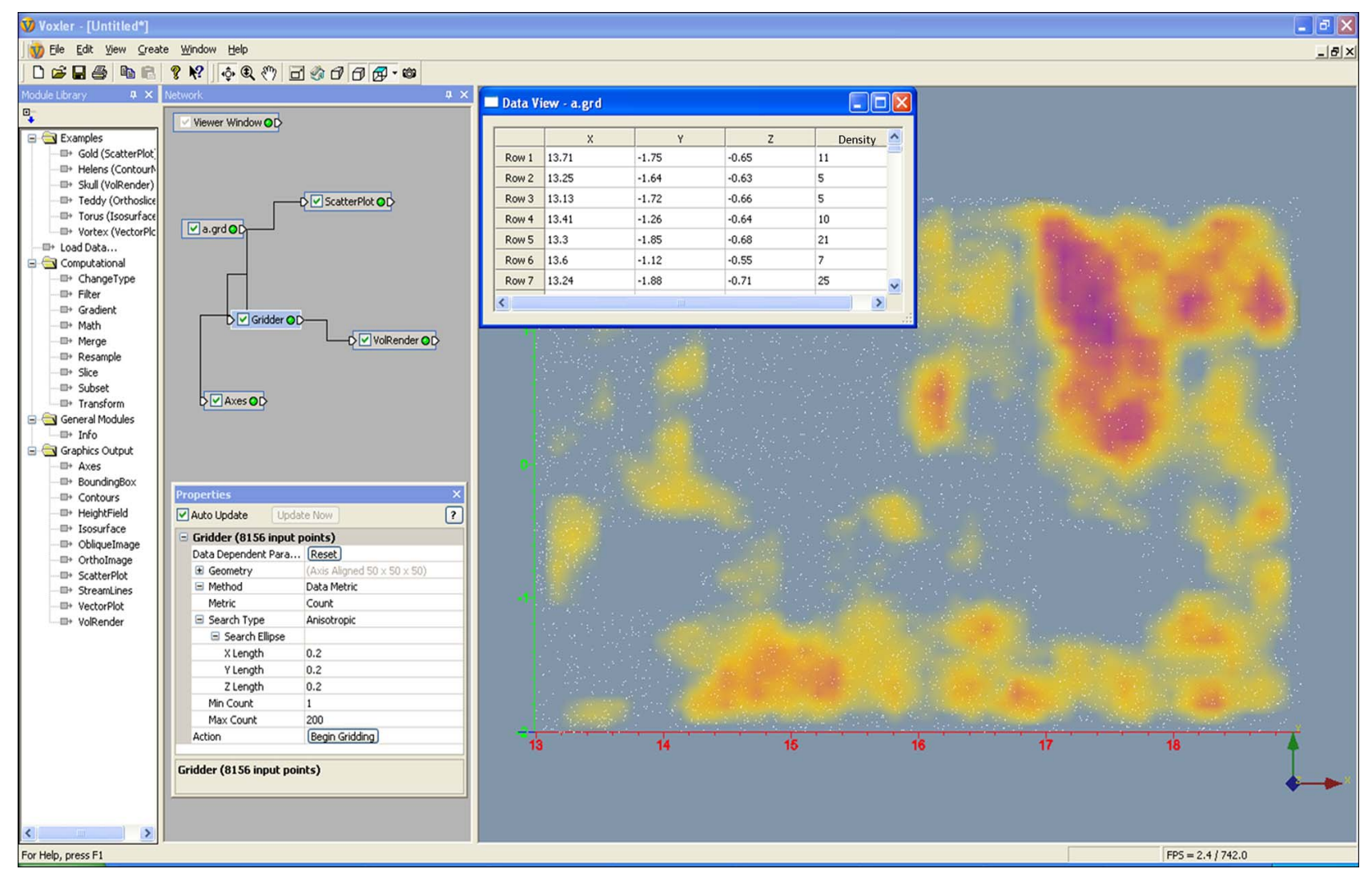

Figure 4.

An example of data elaboration in Voxler ${ }^{\circ}$.

been identified in the central and eastern part of the t.3a in Sector I, where it lies on mudstone (t.3b). Spatial investigation and the revised Sector I stratigraphy advanced the hypothesis that $3 \mathrm{E}$, the debris-flow, could have partially reworked the underlying t.3a (Coltorti et al., 2005). In order to add further spatial analytical components to test this hypothesis, as well as better understand formation mechanisms for this part of the deposit, we explored the spatial distribution of finds in t.3a and $3 \mathrm{E}$ and their relationship to each other. In particular, the density analysis allows us to identify whether the concentrating and dispersing areas in these entities are superimposed.

In this paper we present the preliminary results of the $3 \mathrm{D}$ density analysis of these archaeostratigraphic (sub)units as the first step towards a general revaluation of the formation mechanisms of t.3a deposit using new data from spatial archaeology, geology, sedimentology, stratigraphy and geoarchaeology.

We selected a test area of $24 \mathrm{~m}^{2}$ where both units were completely excavated. We processed two-dimensional density maps for t.3a because it is impossible to reconstruct the $\mathrm{z}$ values of archaeological finds as they have been left in situ for museal purposes. In this case, we considered a two-dimensional analysis representative of the effective spatial density patterns because, as mentioned previously, the finds of t.3a lie on a subhorizontal surface without vertical dislocation. However, the thickness of $3 \mathrm{E}$ required the application of three-dimensional density analysis to explore the vertical location of the density areas in order to evaluate the effective correspondence with the underlying density phenomena identified in t.3a.

The density patterns were calculated using a sphere at a ra- dius of $25 \mathrm{~cm}$. Considering the excavated surface of the studyarea and the thickness of its deposit, the choice of such a radius allowed us the optimal visualization to highlight phenomena of spatial concentration and dispersion of finds.

In order to visualize both units simultaneously, a standard z value was assigned to the finds recorded in t.3a. The resulting maps show the top view of both units (Figures 5(a) and (b)), the front and lateral views of the superimposed units and the relative axonometric view (Figures 5(c)-(e)). Also, we explored the density phenomena by slicing the maps along orthogonal (Figure 6(a)) and oblique planes (Figure 6(b)).

These maps allowed us to recognize that the maximum density in $3 \mathrm{E}$ is located in the lower SE part of the sampled area (Figures 5(b)-(d), 6); this is clearly due to the slope of the debris-flow. This area does not correspond to an equivalent density trend in t.3a, where the maximum concentration of finds is in the NW zone of the same excavated area (Figure 5(a)). Therefore, the spatial patterns obtained in our analysis suggest that action of a geological agent such as the debris-flow has not moved fossils and stone tools of t.3a. If supported by further archaeological and geological data, as well as enlarging the study area, this datum could confirm that the debris-flow $3 \mathrm{E}$ has not reworked or not strongly reworked the underlying unit t.3a and that the formation processes of these two units are completely or nearly independent. In this case, $3 \mathrm{E}$ would not be directly responsible of the random distribution patterns in the central and eastern area of the excavated surface. Likely, the formation processes of the western part and of the central and eastern area of t.3a could be due to two or more distinct (post) 


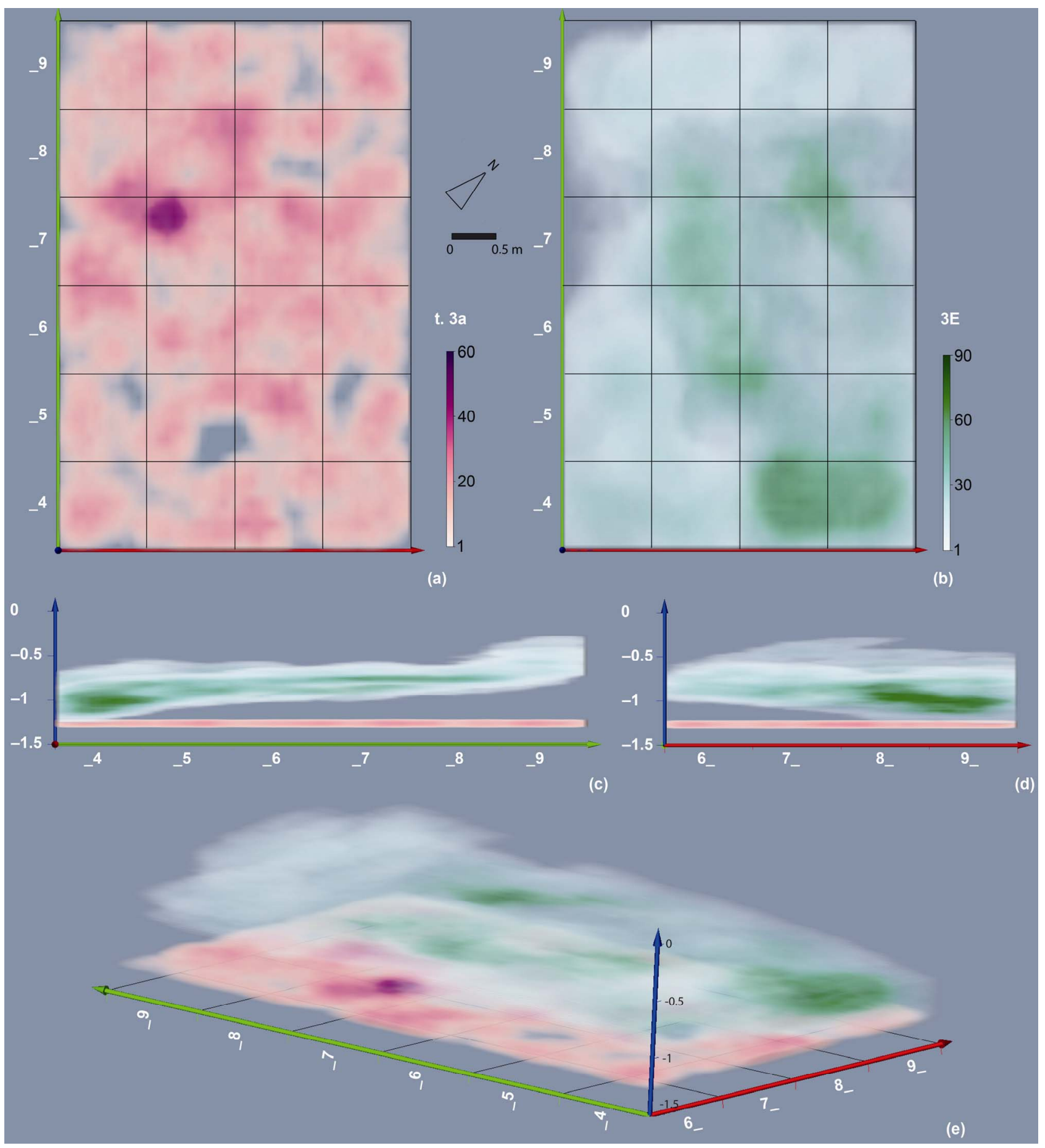

Figure 5.

Isernia La Pineta, Sector I. (a) Density map of t.3a; (b) Density map of 3E; (c) Front view of the density patterns of t.3a and 3E; (d) Lateral view of the density patterns of t.3a and $3 \mathrm{E}$; (e) Axonometric view of the density patterns of t.3a and $3 \mathrm{E}$.

depositional phenomena and not correspond to a single event, as has been assumed previously.

\section{Conclusion}

Density analyses, associated with other archaeological and/or geological criteria, are a useful tool to investigate site formation processes. Because most applications are limited to two dimensions, most archaeological studies allow for only a partial assessment of three-dimensional spatial density patterns, particularly in the case of very thick archaeostratigraphic units.

This project set out to develop a method to process threedimensional density analyses and to visualize the resulting spatial trends. After developing a specific GIS for mapping and 


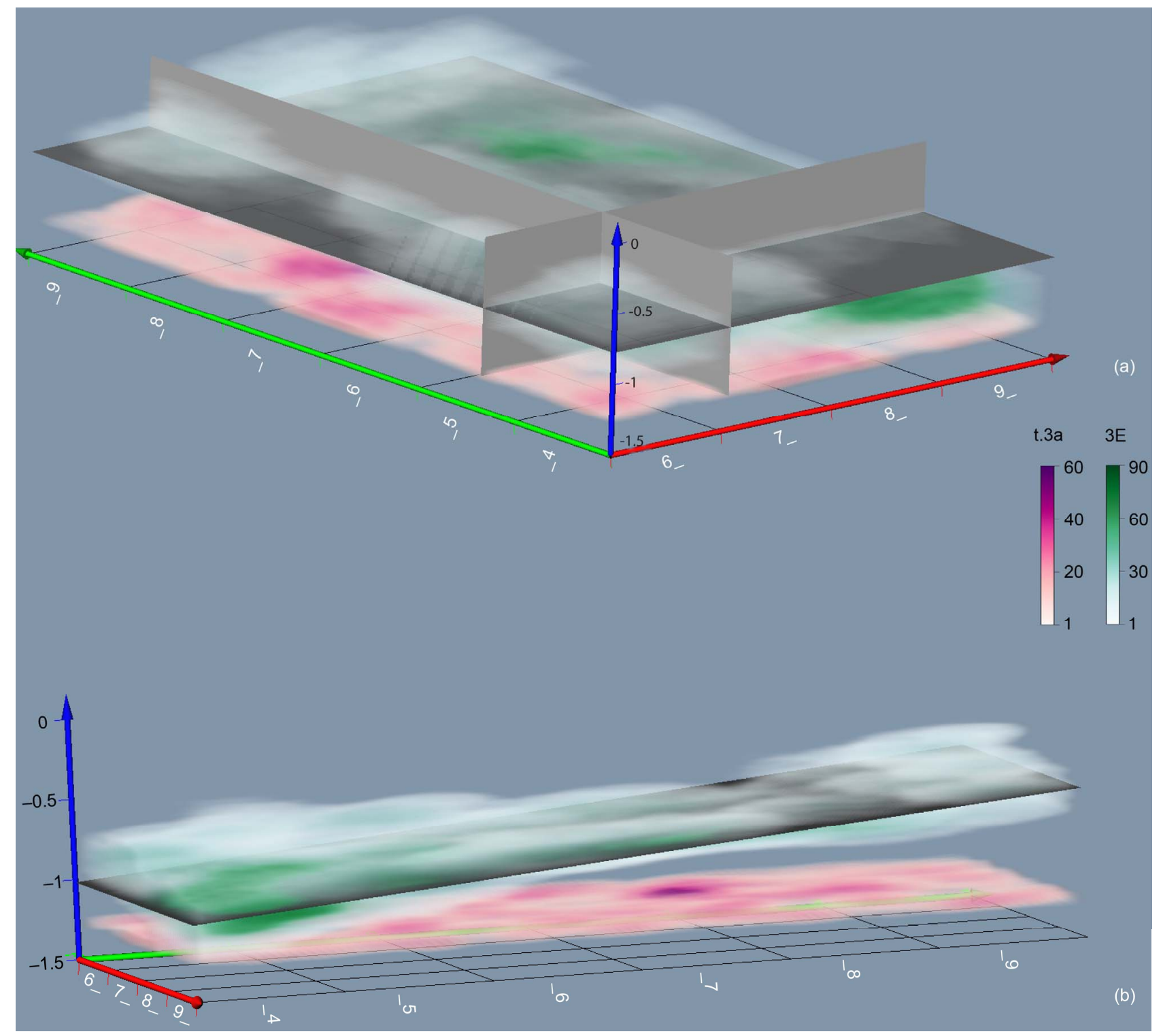

Figure 6.

Isernia La Pineta, Sector I. (a) Orthogonal planes cutting the axonometric view of the density patterns of t.3a and 3E; (b) Oblique plane cutting the axonometric view of the density patterns of t.3a and $3 \mathrm{E}$.

analyzing fossil deposits, we attempt to assess the potential of this method in the reconstruction of depositional and post-depositional mechanisms of the Middle Pleistocene site of Isernia La Pineta. The results show that this model has clear potentials and can be broadly applied to other similar sites.

\section{Acknowledgements}

We thank the Ministero per i Beni e le Attività culturali_for giving permission to Carlo Peretto from the Università degli Studi di Ferrara to conduct research at Isernia La Pineta. We would like to express deep thanks to all institution that financially supported field and laboratory activities (Ministero per i Beni e le Attività culturali, Provincia di Isernia, CERP, Istituto Banco di Napoli-Fondazione, Università degli studi di Ferrara, CNR, PRIN). We thank Université Bordeaux 1, UMR 5199
PACEA-PPP who allowed Rosalia Gallotti to pursue her work at Isernia La Pineta in the frame of a Post-PhD grant of Région Aquitaine.

We thank also Jean-Paul Raynal for his suggestions, Leah Morgan for the English revision, and reviewer for its useful comments.

Finally, we are thankful to those who have given us their constant and continuous collaboration.

\section{REFERENCES}

Anconetani, P., Crovetto, C., Ferrari, M., Giusberti, G., Longo, L., Peretto, C., \& Vianello, F. (1992). Nuove ricerche nel giacimento di Isernia La Pineta (Molise). Rivista di Scienze Preistoriche, XLIV, $3-41$.

Bailey, G. (2007). Time perspectives, palimpsests and the archaeology 
of time. Journal of Anthropological Archaeology, 26, 198-223. doi:10.1016/j.jaa.2006.08.002

Barceló, J. A. (2002). Archaeological thinking: between space and time. Archeologia e Calcolatori, 13, 237-257.

Baxter, M., Beardah, C. C., \& Wright, R. V. S. (1997). Some archaeological applications of Kernel Density Estimates. Journal of Archaeological Science, 24, 347-354. doi:10.1006/jasc.1996.0119

Beardah, C. C. (1999). Uses of multivariate kernel density estimates in archaeology. In L. Dingwall, S. Exon, V. Gaffney, \& S. Laflin (Eds.), Archaeology in the Age of the Internet. Oxford: BAR International Series 750

Beardah, C. C., \& Baxter, M. (1999). Three-dimensional data display using kernel density estimates. In J. Barceló, I. Briz, \& A. Vila (Eds.), New Techniques for Old Times. Proceedings of CAA98 (pp. 163-169). Oxford: Archaeopress.

Benito-Calvo, A., \& De la Torre, I. (2011). Analysis of orientation patterns in Olduvai Bed I assemblages using GIS techniques: Implications for site formation processes. Journal of Human Evolution, 61, 50-60. doi:10.1016/j.jhevol.2011.02.011

Blankholm, H. P. (1991). Intrasite spatial analysis in theory and practice. Aarhus: Aarhus University Press.

Coltorti, M. (1983). Le fasi principali dell'evoluzione del paesaggio nel bacino di Isernia (Molise). In M. Coltorti (Ed.), Isernia La Pineta, un accampamento più antico di 700.000 anni (pp. 41-47). Bologna: Calderini.

Coltorti, M., \& Cremaschi, M. (1982). Depositi quaternari e movimenti neotettonici nella conca di Isernia. Contributi Conclusivi per la carta Neotettonica d'Italia, Consiglio Nazionale Richerche. Progreso Financiero, 506, 173-198.

Coltorti, M., Feraud, G., Marzoli, A., Peretto, C., Ton-That, T., Voinchet, P., Bahain, J.-J., Minelli, A., \& Thun Hohenstein, U. (2005). New ${ }^{40} \mathrm{Ar} /{ }^{39} \mathrm{Ar}$, stratigraphic and palaeoclimatic data on the Isernia La Pineta Lower Palaeolithic site, Molise, Italy. Quaternary International, 131, 11-22. doi:10.1016/j.quaint.2004.07.004

Cooper, J. R., \& Qiu, F. (2006). Expediting and standardizing stone artifact refitting using a computerized suitability model. Journal of Archaeological Science, 33, 987-998. doi:10.1016/j.jas.2005.11.005

Craig, N., Aldenderfer, M., \& Moyes, H. (2006). Multivariate visualization and analysis of photomapped artifact scatters. Journal of Archaeological Science, 33, 1617-1627. doi:10.1016/j.jas.2006.02.018

Cremaschi, M. (1983). La serie pleistocenica di Isernia La Pineta (Molise) e la posizione stratigrafica dei suoli di abitato paleolitici in essa inclusi. In M. Coltorti (Ed.), Isernia La Pineta. Un accampamento più antico di 700.000 anni (pp. 49-62). Bologna: Calderini.

Cremaschi, M., \& Peretto, C. (1988). Les sols d'habitat du site paleolithique d'Isernia La Pineta (Molise, Italie). L'Anthropologie, 92, 643-682.

D’Andrea, A., \& Gallotti, R. (2004). GIS and intra-site spatial analysis. In J. Chavaillon, \& M. Piperno, (Eds.), Studies on the Early Paleolithic Site of Melka Kunture, Ethiopia (pp. 589-597). Firenze: Origines.

D'Andrea, A., Gallotti, R., \& Piperno, M. (2000). Applicazione di un GIS intra-site al giacimento paleolitico di Garba IV (Melka Kunture, Etiopia). Archeologia e Calcolatori, 11, 319-338.

D’Andrea, A., Gallotti, R., \& Piperno, M. (2002). Taphonomic interpretation of the developed Oldowan site of Garba IV (Melka Kunture, Ethiopia) through a GIS application. Antiquity, 76, 991-1001.

Djindjian, F. (1988). Improvements in intrasite spatial analysis techniques. In S. P. Q. Rahtz (Ed.), Computer and Quntitative Methods in Archaeology (pp. 95-106). Oxford: British Archaeological Reports (International Series).

Djindjian, F. (1999). L'analyse spatiale de l'habitat: Etat de l'art. Archeologia e Calcolatori, 10, 17-32.

Gallotti, R. (2004). Analisi spaziali e metodologie computazionali per un approccio cognitivo ai modelli di frequentazione antropica del giacimento di Isernia La Pineta (Molise, Italia). Ph.D. Thesis, Ferrara: Ferrara University.

Gallotti, R., Arzarello, M., Lembo, G., Minelli, A., Thun Hohenstein, U., \& Peretto, C. (2004). Informatic management of the excavation data of Isernia La Pineta (Molise, Italy). Proceedings of the XIV UISPP Congress, Liege, 2-8 September 2002.

Gallotti, R., Mohib, A., El Graoui, M., Sbihi-Alaoui, F.-Z., \& Raynal, J.-P. (2011). GIS and intra-site spatial analyses: An Integrated approach for recording and analyzing the fossil deposits at Casablanca Prehistoric sites (Morocco). Journal of Geographic Information System, 3, 373-381. doi:10.4236/jgis.2011.34036

Gallotti, R., \& Piperno, M. (2004). Prehistoric archaeology. The site of Garba IV. Spatial analysis of the lithic material from Level D. In J. Chavaillon, \& M. Piperno, (Eds.), Studies on the Early Paleolithic site of Melka Kunture, Ethiopia (pp. 599-635). Firenze: Origines.

Hodder, I., \& Orton, C. (1976). Spatial Analysis in Archaeology. Cambridge: CUP.

Jerardino, A. (1995). The problem with density values in archaeological analysis. A case study from Tortoise Cave, Western Cape, South Africa. South African Archaeological Bullettin, 50, 21-27. doi: $10.2307 / 3889271$

Johnson, T. (1976). Contribution méthodologique à l'étude de la répartition des vestiges dans les niveaux archéologiques. Diplôme d'Etudes Supérieures, Bordeaux: University of Bordeaux.

Kintigh, K. W., \& Ammermann, A. J. (1982). Heuristic approaches to spatial analysis in archaeology. American Antiquity, 47, 31-63. doi: $10.2307 / 280052$

Lembo, G., \& Gallotti, R. (2006). L'analisi spaziale intra-site. Trend distributivi dei reperti litici e paleontologici delle archeosuperfici 3c e 3 a del I Settore di scavo. In C. Peretto, \& A. Minelli (Eds.), La Preistoria del Molise. Gli insediamenti nel territorio di Isernia (pp. 96-119). Collana Ricerche del Centro Europeo Ricerche Preistoriche (CERP), 3. Isernia: ARACNE.

Malinsky-Buller, A., Hovers E., \& Marder O. (2011). Making time: 'Living floors', 'palimpsests' and site formation processes-A perspective from the open-air lower paleolithic site of Revadim Quarry, Israel. Journal of Anthropological Archaeology, 30, 89-101. doi:10.1016/j.jaa.2010.11.002

Mitchell, A. (1999). Mapping density. The ESRI Guide to GIS Analysis Volume 1: Geographic Patterns \& Relationships (pp. 69-85). California, ESRI Press.

Moyes, H. (2002). The use of GIS in the Spatial analysis of an archaeological cave site. Journal of Cave and Karst Studies, 64, 9-16.

Nigro, D., De Ruiter, D. J., Berger, L. R., \& Ungar, P. S. (2001). A tridimensional geographic information system for Swartkrans. Meeting of the Paleoanthropology Society, Kansas City.

Nigro, D., Ungar, P. S., De Ruiter, D. J., \& Berger, L. R. (2003). Developing a geographical information system (GIS) for mapping and analysing fossil deposits at Swartkrans, Gauteng Province, South Africa. Journal of Archaeological Science, 30, 317-324. doi:10.1006/jasc.2002.0839

Peretto, C. (1996). I reperti paleontologici del giacimento paleolitico di Isernia La Pineta. Isernia: Cosmo Iannone Editore.

Peretto, C. (1999). I suoli d'abitato del giacimento paleolitico di Isernia La Pineta, natura e distribuzione dei reperti. Isernia: Cosmo Iannone Editore.

Peretto, C., Arzarello, M., Gallotti, R., Lembo, G., Minelli, A., \& Thun Hohenstein, U. (2004). Middle Pleistocene behavioural strategies: the contribution of Isernia La Pineta site. In E. Baquedano, \& S. Rubio Jara (Eds.), Miscelanea en Homenaje a Emiliano Aguirre, Volumen IV, Arqueologia (pp. 369-381). Alcalá de Henares: Museo Arqueologico Regional.

Peretto C., Arzarello M., Gallotti R., Lembo G., Minelli A., \& Thun Hohenstein, U. (2010). The intra-site analysis of the palaeolithic site of Isernia La Pineta (Molise, Italia). In F. Niccolucci, \& S. Hermon (Eds.), Beyond the Artifact. Digital Interpretation of the Past (pp. 201-206). Budapest: Archaeolingua.

Peretto, C., Biagi, P., Boschian, G., Broglio, A., De Stefani, M., Fasani, L., Fontana, F., Grifoni, R., Guerreschi, A., Iacopini, A., Minelli, A., Pala, R., Peresani, M., Radi, G., Ronchitelli, A., Sarti, L., Thun Hohenstein, U., \& Tozzi, C. (2004). Living-floors and structures from the lower paleolithic to the bronze age in Italy. Collegium antropologicum, 28, 63-88.

Petrie, L., Johnson, I., Cullen, B., \& Kvamme, K. (1995). GIS in ar- 


\section{R. GALLOTTI ET AL.}

chaeology: An annotated bibliography. Archaeological Methods Series 1 . Sydney: Sydney University.

Schagen, I.P. (1986). Construction of continuous density functions from spatially distributed categorical data. Applied Mathematical Modelling, 10, 53-56. doi:10.1016/0307-904X(86)90009-0

Shao, Q., Bahain, J.-J., Falguères C., Peretto, C., Arzarello, M., Minelli, A., Thun Hohenstein, U., Dolo, J.-M., Garcia, T., Frank, N., \& Douville, E. (2011). New ESR/U-series data for the early Middle Pleistocene site of Isernia la Pineta, Italy. Radiation Measurements, 46, 847-852. doi:10.1016/j.radmeas.2011.03.026

Shiffer, M. B. (1983). Toward the identification of formation processes. American Antiquity, 48, 675-706. doi:10.2307/279771

Simek, J. F. (1984). A K-means approach to the analysis of spatial structures in Upper Palaeolithic habitation sites: Le Flageolet I and Pincevent Section 36. Oxford: British Archaeological Reports (International Series), 205.

Spikins, P., Conneller, C., Ayestaran, H., \& Scaife, B. (2002). GIS Based interpolation applied to distinguishing occupation phases of early prehistoric sites. Journal of Archaeological Science, 29, 12351245. doi:10.1006/jasc. 2001.0752

Texier, J.-P. (2000). A propos des processus de formation des sites préhistoriques. Paléo, 12, 379-386.

Thomas, J., Potts, R., \& Cole, D. (1996). The role of GIS in the interdisciplinary investigation at Olorgesailie, Kenya, a Pleistocene Archaeological Locality. In M. Aldenderfer, \& H. D. G. Maschner
(Eds.), Anthropology, Space and Geographical Information System (pp. 202-213). New York: Oxford University Press.

Thun Hohenstein, U., Malerba, G., Ghirelli, E., Giacobini, G., \& Peretto, C. (2002). Attività di sussistenza nel paleolitico inferiore di Isernia La Pineta: Archeozoologia delle US 3S10 e 3coll. Rivista di Scienze preistoriche, LII, 1-18.

Van Otterloo, R., \& Sevink, J. (1983). The Quaternary evolution of the Upper Volturno basin. In M. Coltorti (Ed.), Isernia La Pineta. Un accampamento più antico di 700.000 anni (pp. 35-39). Bologna: Calderini.

Vullo, N., Fontana, F., \& Guerreschi, A. (1999). The application of GIS to intra-site spatial analysis: preliminary results from Alpe Veglia (VB) and Mondeval de Sora (BL), two mesolithic sites, in Italian Alpes. In J. Barcelò, I. Briz, \& A. Vila (Eds.), New Techniques for Old Times (pp. 111-115). Oxford: BAR International Series, 757.

Whallon, R. (1984). Unconstrained clustering for the analysis of spatial distributions in archaeology. In H. J. Hietala (Ed.), Intrasite Spatial Analysis in Archaeology (pp. 242-277). Cambridge: Cambridge University Press.

Wheatley, D., \& Gillings, M. (2002). Spatial technology and archaeology. The archaeological applications of GIS. London: Taylor and Francis. doi:10.4324/9780203302392

Yellen, J. (1977). Archaeological approaches to the present. New York: Academic Press. 